\title{
Visitors' Perceptions to Ecotourism Goals and Satisfaction : The Case of Muju Firefly Festival
}

\author{
Gang-Hoan Jeong", Yong-Ho Roh and Wii-Joo Yhang* \\ Division of Culture and Tourism, Pachai University, Daejon 302-735, Korea \\ Division of Theater and Film, Daekyung College, Gyeongsan 712-719, Korea \\ "Division of international Tourism, Silla University, Busan 617-736, Korea \\ (Manuscript received 20 December, 2004; accepted 25 April, 2005)
}

The purposes of this study were to investigate ecotourism goals which are providing educational tourism, generating environmental conservation, and residents' economic benefits based on the 7th Muju Firefly festival. The sample was 243 visitors from August 23rd to 30th, 2003.

The results were as follows: First, visitors showed high satisfaction for the educational tourism program. Experiencing educational "Mysterious Firefly Field Trips" contributed to the tourists' educational satisfaction. It was found that these experience programs were very popular.

Second, residents' and domestic visitors' satisfaction was high with 5.50 on Likert 7 points concerning environmental conservation.

Third, foreigners showed high satisfaction for visiting tourism sites and understanding regional culture in terms of understanding region and economic benefits. The average economic effect was decreased compared to 2002. So there should be more diverse strategy to increase economic effect. Also more festival related products, diverse and unique foods and beverages based on regional products should be developed.

Key Words : Muju Firefly Festival, Ecotourism, Visitors' perceptions

\section{Introduction}

Ecotourism is a popular tourism in the world. It is estimated that there are 35 million ecotourists in the U.S.A. The potential ecotourism market is 45 million ecotourists. And ecotourism will grow 10-15\% annually ${ }^{1)}$. Korea is no exception. Korea National Tourism Organization ${ }^{2 \gamma}$ designated 70 ecotourism sites including the Muju Firefly Festival. The festival attracted more than 500,000 visitors in 2003. It was defined that ecotourism is a responsible form of tourism, which provide minimum influence on the environment and regional society and maximizes economic benefits and satisfies tourists ${ }^{2)}$. The UNESCO, one of the UN suborganization, named year 2002 as the ecotourism year.

The previous study of festival and events are regional festival ${ }^{3)}$, economic effect of events ${ }^{4,5)}$, eco-

Corresponding Author: Yong-ho Roh, Division of Theater and Film, Daekyung College, Gyeongsan 712-719, Korea Phone: +82-53-794-0569

E-mail: yhnoh11@hanmail.net tourism festival ${ }^{6,7)}$. Jeong and $\operatorname{Roh}^{7)}$ evaluated three years'(1999-2001) the Muju Firefly Festival which contained event programs and environmental experiences. Getz $^{8)}$ emphasized the importance of not only economic impact, sponsorship, and marketing but also environmental preservation as the event's goal. However, there is still little ecotourism-type event research that relates to environments ${ }^{9}$.

While the goals of ecotourism are to provide educational tourism, generate environmental conservation, and residents' economic benefits ${ }^{10-12)}$, there is little study which investigates the goals of ecotourism.

The differentiation of this study from previous festival studies is this study investigated ecotourism goals through an ecotourism type festival, the Muju Firefly Festival. The specific purposes of this study were to investigate ecotourism goals which are educational tourism, environmental conservation, and regional economic benefits from festival attending tourists. 


\section{Methods of Research}

\subsection{Study Area}

The Muju county is located in the southwest of Seoul. It was the host city of the Winter Universiad games in 1997. Because the county recognized the importance of having a clean environment, it has used the pollution-free clean image with the Firefly Festival. There were more than 500,000 festival visitors in 2003. The county strategically related to the image of the county's agricultural products and handcrafts. These are Firefly Apples, Firefly grapes, and Firefly tomatoes. The Muju Firefly is the brand name of the county ${ }^{14)}$.

\subsection{Research Method}

This study was conducted using the goals of ecotourism which are providing educational tourism, generating environmental conservation and residents' benefits. The researched factors of this study were educational tourism, environmental conservation, and residents' benefits. The educational tourism was measured by program interesting, and eco-experience. The visitors' environmental conservation was measured based on firefly eco-experience room satisfaction and Mysterious Firefly Field Trips. The residents' benefits was measured by understanding of tourism sites, and understanding regional culture, and economic effect.

The research questions of this study were as follows. First, will this study festival, the Muju Firefly Festival provide educational tourism? Second, will the festival generate environmental conservation? Third, will the festival generate residents' benefits?

This research was conducted with 243 visitors from August 23rd to 30th, 2003. A Self-administered questionnaire survey and interview were conducted. The collected samples were compared through the SPSS statistical package. The frequency and average were used. The 7 point Likert scale, based on the one- way ANOVA and Duncan Multiple Comparison Test, was conducted to compare ecotourism goals and satisfaction among residents, domestic visitors, and foreigners.

\section{Results}

\subsection{Demographical Status}

It was found that visitors consisted of $64.7 \%$ of female and $35.3 \%$ of male as the table 1. Compared to 2002 , which had $58.4 \%$ female and $41.6 \%$ male,
Table 1. Demographic statistics

\begin{tabular}{c|c|c}
\hline \multicolumn{2}{|c|}{ Variables } & $103 \mathrm{~N}(\%)$ \\
\hline \multirow{4}{*}{ Gender } & Male & $157(64.7)$ \\
\cline { 2 - 3 } & Female & $86(35.3)$ \\
\hline \multirow{4}{*}{ Visiting Pattern } & Family & $157(64.6)$ \\
\cline { 2 - 3 } & Friend & $47(19.2)$ \\
\cline { 2 - 3 } & Group & $23(9.6)$ \\
\cline { 2 - 3 } & Alone & $4(1.7)$ \\
\cline { 2 - 3 } & Couple & $8(3.3)$ \\
\cline { 2 - 3 } & Other & $4(1.7)$ \\
\hline \multirow{4}{*}{ Region } & Chungbug & $53(22)$ \\
\cline { 2 - 3 } & Daejeon & $41(16.9)$ \\
\cline { 2 - 3 } & Muju & $37(15.3)$ \\
\cline { 2 - 3 } & Seoul & $25(10.2)$ \\
\cline { 2 - 3 } & Gyunggi & $16(6.8)$ \\
\cline { 2 - 3 } & Gyungnam & $14(5.9)$ \\
\cline { 2 - 3 } & Chungbuk & $7(3.0)$ \\
\cline { 2 - 3 } & Chungnam & $4(1.7)$ \\
\cline { 2 - 3 } & Other & $46(17.9)$ \\
\hline
\end{tabular}

the number of female visitors increased. In terms of visiting type, families were $64.6 \%$, friends were $19.2 \%$. Groups were $9.6 \%$, couples were $3.3 \%$, and alone was $1.7 \%$. Family was the highest visiting type. To learn about fireflies through this firefly festival, parents brought children for education. In terms of visitors came from, Junbuk increased to $22.0 \%$ from last year's $18.0 \%$ and Daejeon decreased to $16.9 \%$ from $22.3 \%$ of last year. Seoul and Gyunggi visitors have increased from $8.1 \%$ to $10.2 \%$ and $4.3 \%$ to $6.8 \%$. The number of visitors from the Seoul area has increased. It was found that the internet, $34.8 \%$ from last year $32.7 \%$ was the main information resource and word of mouth by relatives and friends $(30.3 \%$ to $24.7 \%$ ) were the second at this festival.

\subsection{Ecotourism as Educational Tourism}

The educational tourism was measured by program interest, and eco-experience. It was found that the satisfaction rate about "program appeal" was 5.19 which was comparatively positive as the table 2 . In terms of the core program, there were exhibitions of live insects and fishes. Family groups who brought children were interested in live fishes and insects. Visitors wished to increase educational effect with interpretation about insects and exhibited fishes.

More interpreters are necessary for exhibitions. In the part of eco-experience center, an live firefly room and an artificial firefly corner were provided. They 
Visitors' Perceptions to Ecotourism Goals and Satisfaction: The Case of Muju Firefly Festival

Table 2. Evaluation and Results of ANOVA by each group

\begin{tabular}{c|c|c|c|c}
\hline Group & Residents & Domestics & Foreigners & $\mathrm{F}(\mathrm{P})$ \\
\hline \hline Program Interesting & 5.17 & 5.15 & 6.25 & $3.005(0.051)$ \\
\hline Eco Experience & 4.97 & 5.13 & 6.00 & $1.950(0.145)$ \\
\hline
\end{tabular}

No significant difference among groups

provided positive images. The festival committee provided 27 buses for visitors to join the mysterious firefly field trips compared to 10 buses in 2002 . It provided more chances of experiencing mysterious firefly field trips and contributed to environmental education satisfaction. For the program, the festival committee also provided traditional art exhibits and experiences sightseeing as well traditional foods. The residents' satisfaction rate was 5.17 , domestic tourists rate was 5.15 , and foreign visitors rate were 6.25 .

The average satisfaction point of experience program was 5.14 . The reasons that positively satisfied visitors was the expanded "Visiting of the Mysterious Firefly". This experience program was the item that visitors liked a lot. The reason was also the increase of experience programs in the eco-experience which was the core program with mysterious firefly field trips. Expanding of education based experience programs was found to be as the highest item that should be developed with $33.9 \%$. Next was expansion of convenient facilities with $21.0 \%$. The satisfaction of residents, domestic tourists, and foreign tourists was 4.97, 5.13, and 6.00 .

\subsection{Environmental Conservation}

\subsubsection{Firefly Eco-experience room and Mysterious} Firefly Field Trips

The visitors' concern for environmental conservation was measured based on firefly eco-experience room satisfaction and Mysterious Firefly Field Trips. The comparision between residents and domestic visitors was conducted to provide better program satisfaction and services for the group.

As the table 3 shows, the average satisfaction rate of the firefly eco-experience room was 5.76 which shows high satisfaction. This room had two sections. One emphasized exhibitions and education. The other emphasized experiences. The Education-emphasized part consisted of firefly life exhibition, insects and fishes exhibition, and wild flowers.

The experience-oriented part consisted of making
Table 3. Average satisfaction of firefly eco-experience room

\begin{tabular}{c|c|c|c}
\hline Group & Residents & Domestics & $t(\mathrm{p})$ \\
\hline \hline Eco-experience room & 5.66 & 5.78 & $-0.514(0.607)$ \\
\hline Field trips & 5.91 & 5.95 & $-0.189(0.850)$ \\
\hline
\end{tabular}

No significant difference among groups

wooden insects and experiences of traditional silk, and so on. Providing enough rest space also little bit influenced satisfaction of the firefly eco-room. In the experience programs case, making wooden insects and the experience of making paper animals contributed to the positive image of this festival. However, there were many programs in a limited space. So visitors had difficulty with experiencing and moving the exhibit.

The average satisfaction rate of Mysterious Firefly Field trips was 5.94. The satisfaction was high. More buses (maximum 27 buses a day) compared to last year (maximum 10 buses a day )increased the satisfaction of the experience. Even though visitors who wanted to take firefly field trips had increased, interpreters' numbers had decreased. Guides about the firefly was not sufficiently conducted.

Firefly field trips were conducted even on rainy days and there were few fireflies. But it was found that visitors satisfaction was high. Above all, the visitors' satisfaction of environmental preservation was high.

\subsection{Understanding Region and Economic Benefits}

3.4.1. Visiting tourism sites and Understanding regional culture

It was found that the average satisfaction of visiting well known tourism sites near this festival was 5.09 which showed comparatively positive as the table 4 . The satisfaction of residents, domestic visitors, and foreign tourists were $4.82,5.06$, and 6.63 . There were significant differences between residents-foreign tourists and domestic tourists- foreign tourists.

The average evaluation point of understanding re- 
Table 4. Average satisfaction of visiting well known tourism sites

\begin{tabular}{c|c|c|c|c}
\hline Group & Residents & Domestics & Foreign & $F(P)$ \\
\hline Tourism sites & 4.88 & 5.06 & 6.63 & $3.981(0.020)^{*}(\mathrm{a})$ \\
\hline Regional culture & 5.25 & 5.11 & 6.13 & $2.438(0.090)^{*}(\mathrm{~b})$ \\
\hline
\end{tabular}

(a) Significant difference between residents-foreign and domestics-foreign visitors (b) No significant difference among groups

gional culture was 5.17. Providing the Muju county traditional art and the Muju county traditional food let visitors understand more of the regional cultures. Introducing each sub- county's culture and agricultural products also let visitors understand the regional culture indirectly. But guiding and promotion of home stay facilities which could introduce regional culture were not well introduced to visitors. The satisfaction points by residents, domestic tourists, and foreign tourists was 5.25, 5.11, and 6.13. There were no significant differences among three groups.

\subsubsection{Economic Effect}

It was found that total average expenditure per person was 76,833 Won(approximately-1 US\$ is 1,100 Won) as the table 5 . There was comparision between year 2002 and year 2003 to compare this festival's economic effect. The visitors responded with transportation, accommodation shopping, and other questions as table 5 . It was slightly decreased from 77,368 Won of $2002^{13)}$. Compared to 2002, expenditure, traffic, accommodation, and entertainment were increased, eating and drinking, shopping, and etc (miscellaneous cost) were decreased. In case of traffic cost, it was increased from year 2002's 21,027 Won to 22,572 Won of 2003 . Visitors who came from far away using well made express facilities were main factors. Visiting various programs were also the reason of increased fees.

Accommodation cost had increased from year 2002's 14,486 Won to 17,526 Won. Staying programs including an environmental marathon and mountain bikes, etc by far away visitors attracted their staying over. Also the discount program of Muju resorts and condominium influenced the fees. Shopping cost were decreased from last year's 11,956 Won to 7,950 Won. Economic recession and fewer festival products was the main reasons. It did not encourage visitors' buying motivations. Entertainment costs increased to 5,558 from 4,623 Won of 2002 . The increase of experience cost was the main factor. It was analyzed that visiting
Table 5. Total average expenditure per person

\begin{tabular}{c|c|c|c}
\hline Items & 02 Festival & 03 Festival & \\
\hline Transportation & 21,027 & 22,572 & Increased \\
\hline Food \& Beverage & 20,747 & 20,457 & Decreased \\
\hline Accommodation & 14,486 & 17,526 & Increased \\
\hline Shopping & 11,965 & 7,950 & Decreased \\
\hline Entertainment & 4,623 & 5,558 & Increased \\
\hline Misc. & 4,520 & 2,770 & Decreased \\
\hline Sum of Total Average & 77,368 & 76,833 & Decreased \\
\hline
\end{tabular}

the cinema festival also influenced the experience cost. In terms of eating and drinking, visitors spent 20,457 Won (about US \$) and 20,747 Won of 2002, which is the same. It was found that the major reason for consuming of foods and beverages was the hot weather. Miscellaneous costs decreased to 2,770 Won (US \$) from 4,520 Won.

\section{Conclusions and Suggestions}

This study investigated ecotourism goals based on the Muju Firefly Festival. The results of this study were as follows; First, visitors showed high educational tourism program satisfaction. Experiencing educational" Mysterious Firefly Field Trips" contributed to educational satisfaction. This field trip provided an educational program which visitors can see fireflies which only live in a clean environment. More interpreters are necessary to improve program interest and educational effect.

Second, residents' and domestic visitors' satisfaction was high about environment preservation of this festival. It was found that visitors recognized the importance of environment preservation.

Third, foreigners showed high satisfaction about visiting tourism sites and understanding regional culture. The total average of economic effectiveness was decreased compared to year 2002. So there should be more a diverse strategy to increase economic effect. 
Also, there should be more festival related products. Diverse and unique foods and beverages based on regional products should be developed, too.

The implications of this study are as follows; First, more guides are necessary to increase the educational satisfaction of visiting Mysterious firefly field trips. They should have better knowledge about the firefly and the festival to provide information to the visitors. Second, developing additional experience-based festival programs are necessary. Also, environment friendly programs and more interpreters who can interpret in foreign languages are necessary for this festival.

\section{References}

1) Khan, M. M., 1996, ECOSERV: An Examination of the Service Quality Expectations of the Ecotourists, Ph D. Dissertation, Virginia Polytechnic Institute and State University, 1-259pp.

2) KNTO, http://www.knto.or.kr/Korean/index.html.

3) Getz, D. and W. Frisby, 1996, Evaluating Management Effectiveness in Community Run Festivals, Journal of travel Research(Summer), 27, 22-27.

4) Turco, D. D. and C. W. Kelsey, 1992, Determining the Economic Impact of Recreation Special Events, Alexandria, VA: National Recreation and Park Association, 145pp.

5) Crompton, J. J. and S. L. Mckay, 1994, Measuring the Economic Impact of Festival and Events, Fe- stival management and Event Tourism, 2(1), 3343.

6) Lee, T. D., 1995, Using Visitor Profiles as a means to Attract Exhibitors, Festival Management \& Event Tourism, 2, 217-255.

7) Jeong, G. H. and Y. H. Roh, 2003, The Apprisal of the Muju Firefly Festival, Journal of Tourism and Leisure Research, The Korea Academic Society of Tourism and Leisure, 14(4), 445-459.

8) Getz, D., 1991, Festival, Special Festival \& Tourism, New York: VRN, 65pp.

9) Harris, R., L. K. Jago and M. Huyskens, 2001, Towards an Australian Event Research Agenda: First Steps, Event Management, 6, 213-221.

10) Boo, E., 1990, Ecotourism: The Potential and Pitfalls, Washington, DC, World Wildlife Fund, 1, 55.

11) Ross, S. and G. Wall, 1999, Ecotourism: towards Congruence between Theory and Practice, Tourism Management, 20, 128.

12) Park, S. H., 2002, The Definition of Ecotourism, Tourism Research, Korea Industrial Tourism Research, 17(1), 67-89.

13) Jeong, G. H., 2002, The 2002 Evaluation of the Muju Firefly Festival, The Committee of Muju Firefly Festival, $141 \mathrm{pp}$.

14) Muju Country, 2003, http://www.muju.org/Muju/ home/ localeconomy/ Eo_Farming_Nature.aspx. 